\title{
Assessing the Investment Capacity of the Agricultural Sector: Case of Ukraine
}

\author{
Pavlo Hryhoruk \\ Department of Automated Systems and \\ Modeling in Economics \\ Khmelnytskyi National University \\ Khmelnytskyi, Ukraine \\ violete@ukr.net
}

\author{
Nila Khrushch \\ Department of Finance, Banking and \\ Insurance \\ Khmelnytskyi National University \\ Khmelnytskyi, Ukraine \\ nila.ukr@gmail.com
}

\author{
Svitlana Grygoruk \\ Department of Software Engineering \\ Khmelnytskyi National University \\ Khmelnytskyi, Ukraine \\ grygoruk.svitlana@gmail.com
}

\begin{abstract}
The article is devoted to the problem of estimating the investment potential of the agricultural sector of the economy. The approaches of scientists for the solution of the given task are analyzed. An approach to the estimation of investment potential through block complex valuation technology is proposed. The database is divided into several groups of indicators by their content characteristics. A partial integral index is calculated for each group. The method of normalization of the raw data and the method of convolution of the indicators depend on the nature of the raw data. The resulting metric is calculated as a convolution of partial integral metrics. Practical testing of the proposed approach was carried out for the agricultural sector of the Ukrainian economy. The results of calculations of the integral index are analyzed in dynamics. The results obtained can be used in the development of programs to attract investment in the agricultural sector of the economy.
\end{abstract}

Keywords: Composite index assessment technology, investment capacity, comprehensive index, economic information, data normalization, block convolution, agricultural sector.

\section{INTRODUCTION}

Investments play a crucial role in the economic development of the country and ensure the formation of the production potential of the national economy by updating scientific and technical base. The state and prospects of production development, the level of technical equipment of fixed assets of enterprises, the solution of social and environmental problems of development depend on the effectiveness of investment activity.

Nowadays, there is a need for a holistic approach to solving rural development issues that underpins sustainable development principles. Development of investment capacity is a major component of solving rural development problems.

The concept of investment capacity (potential) is related to the definition of investment attractiveness. The investment attractiveness of rural areas is a system of components of economic capacity that determine the potential interest of investors in investing resources and meet the main goals of investors like break-even, risk-free and investment liquidity. In this context, the importance of research into the theoretical and applied aspects of the investment support of the agricultural sector of the economy, the assessment of investment capacity and the forecasting of the volume of investment attraction are significantly increasing.

This will help to stimulate foreign economic activity, and will be a condition for stable development of the regions. It will help to attract financial and material resources of both domestic and foreign investors, as well as to use them rationally in the most priority sectors of the economy, including in the agricultural sector.

\section{LITERATURE REVIEW}

Studying the problem of attracting investments in the agricultural sector of the economy remains a topical issue, which is within the broad range of scholars' interests. In particular, the study of investment support of the agricultural sector as a complex dynamic system whose purpose is to promote the progressive development both of agriculture and the economic complex as a whole by seeking to attract, distribute and invest funds, material and human resources from different sources, taking into account the cumulative impact of macro-factors. and microenvironment to achieve promising socio-economic goals, are described in [1-12]. They outline the main problematic issues of attracting and using investments in the agricultural sector, in particular, identify the factors that create destabilizing impacts on these processes, set strategic priorities to imply comprehensive implementation of measures to improve the efficiency of investment activities in the agricultural sector.

An important conceptual requirement and a prerequisite for ensuring the efficiency of investments is the use of an adequate methodology for their evaluation, the choice of the correct investment project from some alternative ones, which is a prerequisite for reducing the risks of financial and economic activity and improving its effectiveness.

The theoretical basis of investment analysis is a system of methods and indicators of calculating the effectiveness (attractiveness) of investing. World experience has accumulated a large number of investment analysis techniques and techniques that can be applied to the agricultural sector. Usually, investment analysis of projects is carried out by evaluating and comparing the investment attractiveness (efficiency) of investing destinations, individual programs (projects) or objects.

Currently, there is a wide range of methods for determining the effectiveness of real investment that is acceptable to the agricultural sector of the economy. The first ones are used as express methods for determining the parameters of an investment project in the initial stages of consideration. This group includes rates of return: ARR, ROI, and a discounted payback period. From static methods, these two indicators are the most widely used in practice, mostly in short-term project estimates. In particular, the application of these methods is highlighted in [13, 14].

Dynamic methods where cash flows that occur during project implementation are reduced to an equivalent basis by discounting and provide comparability of different cash flows are characterized by the indicators like NPV, IRR, PI, DPP. The presented methods of analyzing the effectiveness of real investment are generally accepted and basic, which does not exclude the possibility of calculating additional indicators, not only quantitative but also qualitative. The development of 
approaches to the evaluation of investment projects is reflected in [15-17].

Another area of application of mathematical methods in the analysis of the investment process in the agricultural sector is the evaluation of investment attractiveness, which is considered as the level of satisfaction of organizationalmanagerial, financial, production and other requirements or interests of investors [18-22]. In these cases, the models of correlation-regression analysis, rating and scoring models, econometric analysis are widely used.

An approach to the estimation of investment efficiency based on the integral-index method, which reduces to the calculation of the coefficients of operational efficiency and investment activity with their further integration is proposes in paper [23]. Based on the calculations, the author has developed directions for improving the efficiency of regulation of investment processes at the national and regional levels. The basic methods of regulation of investment processes, priority directions of use of state and non-state sources of financing are defined. The main factors that slow down the process of attracting investment are summarized.

Thus, the analysis shows a fairly wide range of models that may be used to evaluate the effectiveness and efficiency of investment activities. At the same time, we note that the direction of using composite index assessment technology to evaluate investment capacity is not sufficiently illuminated in the studies of scholars, so in this study we will consider this approach.

\section{PROBlem DescriPtion AND METhodOlOGY}

Assessment of investment capacity is Important for analyzing the development of any sector of the economy and attracting investment. Investment capacity is a complex, dynamic category that reflects the available resources involved in the economic activity and the variants of its uses taking into account the relationship between its components. The multidimensional structure of this characteristic determines the specifics of shaping a system of its evaluation based on the certain principles.

- Authenticity - the initial data should be publicly available; indicators should be used whose calculation and values are clear and generally accepted.

- Comprehensiveness - the different aspects of investment potential, the full capacity of attraction and the capacity for utilization should be taken into account.

- Practical in nature - the evaluation system must be tailored to the business practice. The results obtained should be the basis for formulating proposals, pointing out ways to improve the existing situation.

- Clarity - graphic and table tools should be used to maximize the perception of results;

- Unambiguous - the results obtained should not allow for double interpretations.

- Unambiguousness - the evaluation system must be tailored to the assessment for different economy's industries, regions, and business entities while taking full account of their specific features.

Investment capacity assessment is based on composite index assessment technology. We will use a variety of this technology based on block assessment of capacity. The evaluation algorithm consists of the following steps:

1) Choosing the set of components of investment potential on the basis of meaningful characteristics.

2) Choosing a set of initial indicators for each component that reflects its most important features.

3) Normalizing indicators, that is, reducing them to a form that eliminates the impact of units on the final result. This will make it impossible to dominate one metric over another and simplify the interpretation of the end result. To reflect the importance of indicators (if necessary), each of them is assigned its value of significance, which is reflected in the weight coefficients.

4) Convolution of indicators into one composite index, study of dynamics and influence of components on the final result.

Let us introduce the notation: $X_{j}$ is the initial indicator; $Z_{j}$ is the normalized indicator; $t=1 . . T, j=1 . . n_{k}, T$ is a number time periods for which calculations are made; $m$ is the number of groups of initial indicators; $n_{k}$ is the number of selected indicators in to the $k$ group of partial indicators, $k=1 . . m$.

The normalization of the initial indicators is carried out by the following formula [24]:

$$
z_{t j}=1-\frac{\left|x_{t j}-x_{j}^{*}\right|}{x_{j \max }-x_{j \min }}
$$

where $z_{t j}$ are normalized values of indicators, $x_{i j}$-values of initial indicators, $x_{j \min }=\min _{t=1 . . T} x_{t j}, x_{j \max }=\max _{t=1 . . T} x_{t j}, j=1 .$. $n_{k}$.

Values $x_{j}^{*}$ are obtained using the formula:

$$
x_{j}^{*}=\left\{\begin{array}{ll}
x_{j \max }, & \text { when } X_{j} \text { is a incentive; } \\
x_{j \min }, & \text { when } X_{j} \text { is a disincentive; }
\end{array}\right. \text {. }
$$

When indicators $X_{j}$ are relative measures of dynamics, we propose to make transformation using the formula:

$$
z_{t j}=\left\{\begin{array}{l}
\frac{x_{t j}}{x_{j \max }}, \text { when } X_{j} \text { is an incentive; } \\
\frac{x_{\text {jmin }}}{x_{t j}}, \text { when } X_{j} \text { is a disincentive; }
\end{array}\right.
$$

It should be noted, there are other ways to normalize data depending on the origin of the indicator and its behavior.

We can use one of the convolution rules to construct a partial composite index for the k-group of initial indicators:

$$
\begin{gathered}
I_{k}=\sum_{j=1}^{n_{k}} w_{j}^{(k)} Z_{j}^{(k)}, \\
I_{k}=\prod_{j=1}^{n_{k}}\left(Z_{j}^{(k)}\right)^{w_{j}^{(k)}}, \\
I_{k}=-1+\prod_{j=1}^{n_{k}}\left(1+Z_{j}^{(k)}\right)^{w_{j}^{(k)}},
\end{gathered}
$$

subject to: 


$$
\sum_{j=1}^{n_{k}} w_{j_{k}}=1
$$

where $w_{j}^{(k)}$ is a weight coefficient of $j$-th initial normalized indicator $Z_{j}^{(k)}$ of $k$-th group.

The convolution of partial composite indexes into one comprehensive index of investment capacity is carried out using one of formulas (4) - (6). In particular, in the case of a linear weighted convolution, the rule will look like as:

$$
I=\sum_{j=1}^{m} w_{j} I_{j}
$$

where $w_{j}$ is a weight of $j$-th partial composite index $I_{j}$.

These weights are determined in proportion to the number of initial indicators of appropriate groups:

$$
w_{j}=\frac{n_{j}}{\sum_{j=1}^{m} n_{j}} .
$$

Therefore, the more partial indicators are included in the group, the greater the weight of the respective component of the investment capacity.

There are currently no formal rules for favoring a particular kind of convolution. From our point of view, if initial indicators are data measured on an absolute scale and normalized by rule (1), then it is advisable to use formulas (4) or (6) for convolution of indicators. If the initial data are relative indicators of dynamics and normalized by rule (3), then it is logical to use formula (5).

\section{RESULTS AND DISCUSSIONS}

Let us evaluate the level of investment capacity of the agricultural sector of the Ukrainian economy by the proposed approach. In this case, we distinguish the following components of investment capacity like:

- resource component;

- personnel component;

- productive component.

So, we have three sets of metrics $(m=3)$, which are groups of partial indicators. For each group, we define an appropriate system of indicators that fill it:

1) Resource component:

- $X_{1}^{(1)}$ - value of fixed assets, million UAH;

- $X_{2}^{(1)}$ - the cumulative index of agricultural production costs, percent;

- $X_{3}^{(1)}$ - area of agricultural land, thousand ha.

2) Personnel component:

- $X_{1}^{(2)}$ - the number of employees, thousand people;

- $X_{2}^{(2)}$ - rural population aged 16-59 years, thousand people.

3) Productive component:

- $X_{1}^{(3)}$ - agricultural production, million UAH;

- $X_{2}^{(3)}-$ Gross value added at actual prices, million $\mathrm{UAH}$;
- $X_{3}^{(3)}$ - financial result before tax, UAH million;

- $X_{4}^{(3)}$ - labor productivity per employee, UAH;

- $X_{5}^{(3)}$ - profit-making enterprises, as a percentage of the total;

- $X_{6}^{(3)}$ - the level of profitability of all activity, percent;

- $X_{7}^{(3)}$ - the level of profitability of operating activities, percent.

The base of economic information for the calculations is the data of the State Statistics Service of Ukraine [25].

We use the data for five years $(T=5)$ in the calculations. In doing so, we take into account that the investment capacity should be evaluated before it is used. That is, there is a lag in the use of investment capacity, so we will select the data for the period from 2013 to 2017 for the calculations. The initial data for analysis are presented in Tables $1-3$.

TABLE I. INDICATOR'S VALUES FOR RESOURCE COMPONENT OF INVESTMENT CAPACITY

\begin{tabular}{|c|c|c|c|c|c|}
\hline \multirow{2}{*}{ Indicator } & \multicolumn{5}{|c|}{ Indicator's values } \\
\cline { 2 - 6 } & $\mathbf{2 0 1 3}$ & $\mathbf{2 0 1 4}$ & $\mathbf{2 0 1 5}$ & $\mathbf{2 0 1 6}$ & $\mathbf{2 0 1 7}$ \\
\hline$X_{1}^{(1)}$ & 156013 & 171392 & 210169 & 270467 & 341622 \\
\hline$X_{2}^{(1)}$ & 101.0 & 117.9 & 150.9 & 113.5 & 121.8 \\
\hline$X_{3}^{(1)}$ & 41525.8 & 41511.7 & 41507.9 & 41504.9 & 41489.3 \\
\hline
\end{tabular}

TABLE II. INDICATOR'S VALUES FOR PERSONNEL COMPONENT OF INVESTMENT CAPACITY

\begin{tabular}{|c|c|c|c|c|c|}
\hline \multirow{2}{*}{ Indicator } & \multicolumn{5}{|c|}{ Indicator's values } \\
\cline { 2 - 6 } & $\mathbf{2 0 1 3}$ & $\mathbf{2 0 1 4}$ & $\mathbf{2 0 1 5}$ & $\mathbf{2 0 1 6}$ & $\mathbf{2 0 1 7}$ \\
\hline$X_{1}^{(2)}$ & 652.1 & 596.0 & 569.4 & 583.4 & 558.1 \\
\hline$X_{2}^{(2)}$ & 8442.1 & 7911.9 & 7855.4 & 7792.1 & 7707.6 \\
\hline
\end{tabular}

TABLE III. INDICATOR'S VALUES FOR PRODUCTIVE COMPONENT OF INVESTMENT CAPACITY

\begin{tabular}{|c|c|c|c|c|c|}
\hline \multirow{2}{*}{ Indicator } & \multicolumn{5}{|c|}{ Indicator's values } \\
\cline { 2 - 6 } & 2016 & 2017 & 2015 & 2016 & 2017 \\
\hline$X_{1}^{(3)}$ & 307054 & 371189 & 544206 & 637791 & 707792 \\
\hline$X_{2}^{(3)}$ & 132354 & 161145 & 239806 & 279701 & 305194 \\
\hline$X_{3}^{(3)}$ & 15012.7 & 21495.9 & 101996.1 & 90122.1 & 68606.5 \\
\hline$X_{4}^{(3)}$ & 201216.9 & 227753.4 & 223309.9 & 275317.8 & 271491.4 \\
\hline$X_{5}^{(3)}$ & 69.8 & 84.8 & 89.0 & 88.4 & 86.8 \\
\hline$X_{6}^{(3)}$ & 8.3 & 9.3 & 30.4 & 25.6 & 16.5 \\
\hline$X_{7}^{(3)}$ & 11.7 & 21.4 & 43.0 & 33.6 & 23.2 \\
\hline
\end{tabular}


The normalized values of the indicators as well as the values of the partial integral indexes for each component of the investment capacity are shown in Tables $4-6$.

Since we don't have any information on the importance of individual partial indicators for each component of the investment capacity, we assume the weighting coefficients in formula (7) are equal within each group:

- for resource component: $w_{j}^{(1)}=1 / 3, j=1 . .3$;

- for personnel component $w_{j}^{(2)}=1 / 2, j=1,2$;

- $\quad$ for productive component $w_{j}^{(3)}=1 / 7, j=1 . .7$.

TABLE IV. NORMALIZED VALUES OF INITIAL INDICATORS AND VALUES OF PARTIAL COMPOSITE INDEX FOR RESOURCE COMPONENT OF INVESTMENT CAPACITY

\begin{tabular}{|c|c|c|c|c|c|}
\hline \multirow{2}{*}{ Indicator } & \multicolumn{5}{|c|}{ Indicator's value } \\
\cline { 2 - 6 } & 2013 & $\mathbf{2 0 1 4}$ & $\mathbf{2 0 1 5}$ & $\mathbf{2 0 1 6}$ & 2017 \\
\hline$Z_{1}^{(1)}$ & 0.00 & 0.08 & 0.29 & 0.62 & 1.00 \\
\hline$Z_{2}^{(1)}$ & 0.00 & 0.34 & 1.00 & 0.25 & 0.42 \\
\hline$Z_{3}^{(1)}$ & 1.00 & 0.61 & 0.51 & 0.43 & 0.00 \\
\hline$I_{1}$ & 0.33 & 0.35 & 0.60 & 0.43 & 0.47 \\
\hline
\end{tabular}

TABLE V. NORMALIZED VALUES OF INITIAL INDICATORS AND VALUES OF PARTIAL COMPOSITE INDEX FOR PERSONNEL COMPONENT OF INVESTMENT CAPACITY

\begin{tabular}{|c|c|c|c|c|c|}
\hline \multirow{2}{*}{ Indicator } & \multicolumn{5}{|c|}{ Indicator's value } \\
\cline { 2 - 6 } & 2013 & $\mathbf{2 0 1 4}$ & $\mathbf{2 0 1 5}$ & $\mathbf{2 0 1 6}$ & $\mathbf{2 0 1 7}$ \\
\hline$Z_{1}^{(2)}$ & 1.00 & 0.40 & 0.12 & 0.27 & 0.00 \\
\hline$Z_{2}^{(2)}$ & 1.00 & 0.28 & 0.20 & 0.12 & 0.00 \\
\hline$I_{2}$ & 1.00 & 0.34 & 0.16 & 0.19 & 0.00 \\
\hline
\end{tabular}

TABLE VI. NORMALIZED VALUES OF INITIAL INDICATORS AND VALUES OF PARTIAL COMPOSITE INDEX FOR PRODUCTIVE COMPONENT OF INVESTMENT CAPACITY

\begin{tabular}{|c|c|c|c|c|c|}
\hline \multirow{2}{*}{ Indicator } & \multicolumn{5}{|c|}{ Indicator's value } \\
\cline { 2 - 6 } & 2013 & 2014 & 2015 & 2016 & 2017 \\
\hline$Z_{1}^{(3)}$ & 0.00 & 0.16 & 0.59 & 0.83 & 1.00 \\
\hline$Z_{2}^{(3)}$ & 0.00 & 0.17 & 0.62 & 0.85 & 1.00 \\
\hline$Z_{3}^{(3)}$ & 0.00 & 0.07 & 1.00 & 0.86 & 0.62 \\
\hline$Z_{4}^{(3)}$ & 0.00 & 0.36 & 0.30 & 1.00 & 0.95 \\
\hline$Z_{5}^{(3)}$ & 0.00 & 0.78 & 1.00 & 0.97 & 0.89 \\
\hline$Z_{6}^{(3)}$ & 0.00 & 0.05 & 1.00 & 0.78 & 0.37 \\
\hline$Z_{7}^{(3)}$ & 0.00 & 0.31 & 1.00 & 0.70 & 0.37 \\
\hline$I_{3}$ & 0.00 & 0.27 & 0.79 & 0.86 & 0.74 \\
\hline
\end{tabular}

The values of resulting comprehensive index of investment capacity calculated by the formula (8) with taking into account expression (9) are shown in the Table 7.

TABLE VII. THE VALUES OF RESULTING COMPREHENSIVE INDEX OF INVESTMENT CAPACITY

\begin{tabular}{|c|c|c|c|c|c|}
\hline \multirow{2}{*}{ Indicator } & \multicolumn{5}{|c|}{ Indicator's value } \\
\cline { 2 - 6 } & $\mathbf{2 0 1 3}$ & $\mathbf{2 0 1 4}$ & $\mathbf{2 0 1 5}$ & $\mathbf{2 0 1 6}$ & $\mathbf{2 0 1 7}$ \\
\hline$I$ & 0.25 & 0.30 & 0.64 & 0.64 & 0.55 \\
\hline
\end{tabular}

Analyzing the result of the calculation of the investment capacity comprehensive index, we can draw the following conclusions. The highest capacity values were observed in 2015 and 2016. It should be noted, that the values of individual indicators in 2017, both those directly included in the model and those indirectly reflecting the use of investment capacity, are decreased.

Let us calculate the relation between the volume of capital investments and the comprehensive index of investment capacity and its components. A common measure of such a relationship is the Pearson correlation coefficient. At the same time. we take into account the lag of the investment capacity indicators. that is. we take the value of the indicator of the volume of attracted capital investments. million UAH. for the period from 2014 to 2018 (Table 8). The corresponding values of Pearson correlation coefficients are shown in Table 9.

TABLE VIII. THE VALUES OF THE INDICATOR OF THE ATTRACTED CAPITAL INVESTMENTS VOLUME

\begin{tabular}{|c|c|c|c|c|}
\hline \multicolumn{5}{|c|}{ Indicator's value } \\
\hline 2014 & $\mathbf{2 0 1 5}$ & $\mathbf{2 0 1 6}$ & $\mathbf{2 0 1 7}$ & $\mathbf{2 0 1 8}$ \\
\hline 18796 & 30155 & 50484 & 64243 & 66104 \\
\hline
\end{tabular}

TABLE IX. THE VALUES OF PEARSON CORRELATION COEFFICIENT BETWEEN THE INDICATOR OF THE ATTRACTED CAPITAL INVESTMENTS VOLUME AND COMPOSITE/ COMPREHENSIVE INDEXES

\begin{tabular}{|c|c|c|c|c|}
\hline $\begin{array}{c}\text { Title of } \\
\text { indicator }\end{array}$ & \multicolumn{4}{|c|}{ Value } \\
\hline $\begin{array}{c}\text { Composite/ } \\
\text { Comprehensive } \\
\text { index }\end{array}$ & $I_{1}$ & $I_{2}$ & $I_{3}$ & $I$ \\
\hline $\begin{array}{c}\text { Pearson } \\
\text { correlation } \\
\text { coefficient value }\end{array}$ & -0.8701 & 0.6186 & 0.9503 & 0.9036 \\
\hline
\end{tabular}

As the results show, there is a close relationship between the volume of capital investments and the composite and comprehensive indexes of investment capacity, which indirectly confirms the impact of the potential on the amount of capital investments attracted. It should be noted, that the human component of the potential has the inverse correlation, which contradicts common sense and economic interpretation of this component. Therefore, it can be concluded from this fact that the personnel component doesn't have a significant impact on the attraction of investments. The situation can be remedied by including indicators that reflect the qualifications of employees in this component.

Let us shape a regression model for the comprehensive index of investment capacity and indicator of the volume of capital investments. The results are shown in Table 10. 
TABLE X. CHARACTERISTICS OF THE REGRESSION MODEL FOR THE COMPREHENSIVE INDEX OF INVESTMENT CAPACITY AND INDICATOR OF THE VOLUME OF CAPITAL INVESTMENTS

\begin{tabular}{|c|c|c|c|c|c|c|}
\hline \multirow[t]{2}{*}{ Model } & \multicolumn{4}{|c|}{$\begin{array}{c}\text { Evaluation of model } \\
\text { parameters by } \\
\text { Student's t-test }\end{array}$} & \multicolumn{2}{|c|}{$\begin{array}{c}\text { Assessment of the } \\
\text { significance of the } \\
\text { model using } \\
\text { Fisher criterion }\end{array}$} \\
\hline & $t_{a 0}$ & $p_{a 0}$ & $t_{a 1}$ & $p_{a 1}$ & $\boldsymbol{F}$ & $p_{F}$ \\
\hline$Y=2121.6+101137.7 \cdot I$ & 8.38 & 0.003 & 13.26 & 0.001 & 13.3 & 0.035 \\
\hline
\end{tabular}

The analysis of the obtained results shows that increase of the value of investment capacity of 0.1 may lead to increase the volume of capital investments in the amount of 10113.8 million UAH. Thus, increasing the level of investment potential of the agricultural sector of the Ukrainian economy can help attract capital investment in this sector

\section{CONCLUSION}

The paper presents an approach to assessing the investment capacity of the agrarian sector of the economy, which uses the composite index assessment technology. It is based on a block convolution of initial indicators. Practical testing of the proposed approach was carried out for the data of the agricultural sector of the Ukrainian economy. For this purpose, the initial indicators were divided into three sets: resource, personnel and productive components. A partial composite index of investment potential was designed for each group, and a comprehensive index of investment capacity was calculated using their values. It is concluded that the highest level of investment potential was observed in 2015 and 2016. We constructed a lag regression model that showed the relationship between the level of investment capacity and the volume of capital investments. The results obtained may be used in the development of programs to attract investment in the agricultural sector of the Ukrainian economy. The presented approach may be used to assess the investment capacity for other sectors of the economy when appropriate choosing the system of indicators that characterize it.

\section{REFERENCES}

[1] S. Benin, E. Nkonya, G. Okecho, J. Randriamamonjy, E. Kato, G. Lubade and M. Kyotalimye, "Returns to spending on agricultural extension: the case of the National Agricultural Advisory Services (NAADS) programme of Uganda," Agricultural Economics, vol. 42, iss. 2, pp. 249-267, Feb. 2011,

[2] S. Syed and M. Miyazako, Promoting Investment in Agriculture for Increased Production and Productivity, Rome, Italy: FAO, Mar. 2013. [Online]. Available: http://www.fao.org/3/a-az725e.pdf. [Accessed 17 Jan 2020]

[3] S. Bisaliah, S. Mahendra Dev and S. Syed, Investment in Indian agricolture: macro and micro evidences, New Delhi, India: Academic Foundation, 2013

[4] S. Waleerat and T. Nipawan, "Analysis of International Investments in the Agricultural Sector of Thailand. Prepared for FAO," Rome, Italy: FAO, Country Rep., 2011. [Online]. Available: http://www.fao.org/fileadmin/templates/tci/pdf/InternationalInvestme nt/Thai/Revised_FDI_Thai_Agri_Final_Formatted.pdf. [Accessed 20 Jan 2020]

[5] M. Barre, Investment as a Means to Agricultural and Rural Development in Africa: A Study on the Investment Needs for Agriculture and Rural Development. Prepared for the FAO, Rome, Italy: FAO, 2006

[6] Trends and Impacts of Foreign Investment in Developing Country Agriculture. Evidence from case studies, 2012. [Online]. Available: https://www.maff.go.jp/j/kokusai/kokkyo/toushi/pdf/faoeibun1.pdf. [Accessed 17 Jan 2020]
[7] V. Ulanchuk, O. Zharun, S. Sokolyuk and S. Tkachuk, "Innovation and investment development of agro-industrial complex," Financial and Credit Activity: Problems of Theory and Practice, iss. 2, pp. 357-365, 2018

[8] S. Syrtseva and O. Melnyk. "Infrastructure Activation of Innovative Development of Ukrainian Agrarian Sector," Baltic Journal of Economic Studies, vol. 3, no. 5, pp. 2017, doi: http://dx.doi.org/10.30525/2256-0742/2017-3-5-400-406

[9] O. S. Sivash, D. D. Burkaltseva and D. S. Ushakov, "Activization of investment process in the agrarian sector," International Journal of Ecology and Development, vol. 32, no. 4, pp.169-182, 2017

[10] O. V. Mityay, "Assessment of competitive capacity of agrarian sector branches," Actual Problems of Economics, iss. 4, pp. 213-220, 2016

[11] J. Zhan, H. Mirza and W. Speller, "The Impact of Larger Scale Agricultural Investments on Communities in South East Asia: A First Assessment," International Development Policy, no. 6, pp. 81-107, 2015. [Online]. Available: https://journals.openedition.org/poldev/2029. [Accessed 22 Jan 2020]

[12] M. Odnorog, N. Kraus and O. Zagurskiy, "Institutional Support for Attracting Investments in The Agrarian Sector of the Economy in the Conditions of Innovative Development, “ Baltic Journal of Economic Studies, vol. 5, no. 1, pp. 143-149, 2019. doi: http://dx.doi.org/10.30525/2256-0742/2019-5-1-143-149

[13] N. Koziar, "Methodical approaches to the evaluation of investment activity of agricultural enterprises," Agrosvit, vol. 16, pp. 67-76, 2019. doi: $10.32702 / 2306-6792.2019 .16 .67$

[14] I. V. Bezpiata, Investment support for the agricultural sector of the economy, Mykolaiv, Ukraine: MNAU, 2016

[15] S. Prodanov. "New Dimensions in the Assessment of Investment Projects". in Capital Budgeting, Veliko Tarnovo, Czech Republic: ABAGAR, 2012. [Online]. Available: https://www.researchgate.net/publication/336126980_NEW DIMEN SIONS_IN_THE_ASSESSMENT_OF_INVESTMENT_PROJECTS. [Accessed 22 Jan 2020]

[16] O. Krioni, N. Efimenko, S. Pashchenko and V. Boltyrov, "Assessment of Investment Attractiveness of Agroindustrial Complex in Republic of Bashkortostan," Advances in Economics, Business and Management Research, vol. 38, pp. 367-372, 2017. [Online]. Available: https://www.atlantis-press.com/proceedings/ttiess-17/25885463. [Accessed 20 Jan 2020]. https://doi.org/10.2991/ttiess-17.2017.6

[17] K. K. Johansson and T. Pekkala, "Portfolio Capacity," Jul. 2013. [Online]. https://papers.ssrn.com/sol3/papers.cfm?abstract id=2200855. [Accessed 22 Jan 2020]. doi: http://dx.doi.org/10.2139/ssrn.2200855

[18] I. I. Petrenko, "Rating Assessment of Investment Potential of Agricultural Enterprises," (in Ukrainian), Scientific Works of Poltava State Agrarian Academy. Economic Sciences, iss. 2, vol. 3, pp. 204215,2011

[19] I. Vinichenko and T. Shutko, "The Matrix Model for Assessing the Investment Attractiveness of Agricultural Enterprises," Baltic Journal of Economic Studies, vol. 5, no. 3, pp. 10-16, 2019, doi: https://doi.org/10.30525/2256-0742/2019-5-3-9-16

[20] M. Odnorog, "Mathematical Modeling in Management of Investment Appeal of Agricultural Agribusines," (in Ukrainian), Scientific Bulletin of UNU. Series: International Economic Relations And World Economy, iss. 6(2), pp. 142-145, 2016

[21] L. V. Borovik, "Evaluation of the Influence of the Investment Policy on the Formation and Use of the Investment Potential of the Sector," (in Ukrainian), Scientific View: Economics and Management, no. 1(59), pp. 72-78, 2018

[22] Y. Y. Demyan, "Estimation of the Inestmant Attractiveness of Agricultural Sector of Economy," (in Ukrainian), Scientific Bulletin of Kherson State University. Series “Economic Sciences”, iss. 12, no. 1, pp.123-123, 2015

[23] V. Geraimovich, "Effectiveness of regulation of investment activity in the sphere of agro-industrial production of the Kiev region," (in Ukrainian), Collection of Scientific Works of Tavrida State Agrotechnological University (Economic Sciences), no. 2(4), pp. 4658,2013

[24] P. Hryhoruk, N. Khrushch and S. Grygoruk, "An approach to design a composite index of economic development and identifying the bounds of its levels," in Proceedings of the 2019 9th International Conference on Advanced computer information technologies ASIT'2019, pp. 4851,2019

[25] State Statistics Service of Ukraine (in Ukrainian). http://www.ukrstat.gv.ua/ [Accessed 24 Jan 2020] 